\title{
DIMENSIONAL STABILIZATION OF WOOD BY CHEMICAL MODIFICATION USING ISOPROPENYL ACETATE
}

\author{
B.N. Giridhar , K.K. Pandey ${ }^{l, \&}$, B.E. Prasad ${ }^{1}$, S.S. Bisht ${ }^{1}$, H.M. Vagdevi ${ }^{2}$
}

\begin{abstract}
Chemical modification of wood with isopropenyl acetate (IPA) using iodine $\left(\mathrm{I}_{2}\right)$ as catalyst has been carried out. Rubber wood (Hevea brasiliensis) specimens were reacted with IPA using iodine $\left(\mathrm{I}_{2}\right)$ catalyst at $95^{\circ} \mathrm{C}$ up to $10 \mathrm{~h}$ under solvent free conditions. The effect of catalyst concentration and reaction time was studied. The extent of acetylation was measured by determining weight percent gain and the modified wood was characterized by FTIR-ATR and ${ }^{13} \mathrm{C}$ NMR spectroscopy. It was found that IPA in the presence of iodine is an excellent acylating reagent for wood. Modified wood exhibited high dimensional stability.
\end{abstract}

Keywords: Chemical modification, dimensional stability, iodine, isopropenyl acetate, rubberwood.

\section{INTRODUCTION}

Wood is hygroscopic, dimensionally unstable especially in high humidity environment and prone to biological decay due to fungus and other microorganisms (Rowell 1983, 2013). All the major cell wall constituents of wood (lignin, cellulose and hemi-celluloses) contain an abundance of free hydroxyl groups. These free hydroxyl groups absorb and release water upon changes in the climatic conditions resulting in dimensional movements of wood. The dimensional stability and biological resistance of wood can be improved considerably by chemical modification by converting hydrophilic -OH groups of cell wall components into larger more hydrophobic groups by forming covalent bonds (Rowell 1983, 2013, Matsuda 1996, Hill 2006). Modification with thermosetting resins improves compression strength and performance against marine borers (Lopes et al. 2014, 2015). Treatment with tall oils also reduced water absorption (Can and Sivrikaya 2016). Modified wood has outstanding dimensional stability, improved durability towards insects and micro-organisms.

Chemical modification of grounded wood has been carried out by transesterification with vinyl esters (Jebrane et al. 2009). Giridhar and Pandey (2016) reported chemical modification of wood by transesterification using IPA in presence of $\mathrm{AlCl}_{3}$ as catalyst and examined dimensional stability and UV resistance of modified wood. In this work, chemical modification of wood with isopropenyl acetate (IPA) in presence of iodine $\left(\mathrm{I}_{2}\right)$ catalyst was carried out. The reaction of wood with IPA forms acetone as byproduct (Figure 1) which can be easily removed from modified wood.

\footnotetext{
${ }^{1}$ Institute of Wood Science and Technology, $18^{\text {th }}$ Cross Malleswaram, Bengaluru, India

${ }^{2}$ Department of Chemistry, Sahyadri Science College, Kuvempu University, Shimoga, India.

•Corresponding author: kkpandey@icfre.org; kkpandey77@gmail.com

Received: 30.05.2016 Accepted: 02.10.2016
} 
<smiles>C=C(C)OC(C)=O</smiles>

Figure 1. Scheme of reaction between wood and isopropenyl acetate (IPA).

\section{MATERIALS AND METHODS}

The specimens of rubberwood (Hevea brasiliensis) measuring $20 \times 20 \times 10 \mathrm{~mm}^{3}$ were prepared from defect free wood. Specimens were extracted with a mixture of ethanol:acetone:toluene (1:1:4) for $6 \mathrm{~h}$ in a Soxhlet apparatus and then oven dried at $100-105^{\circ} \mathrm{C}$ and their weights were determined.

Isopropenyl acetate (IPA) (99\% AR Grade) was purchased from M/s Sigma Aldrich, Bengaluru, India. Iodine $\left(\mathrm{I}_{2}\right)$ (AR Grade) was purchased from M/s SD Fine Chemicals, Bengaluru, India. Ovendried specimens of rubberwood were reacted with IPA in a reaction vessel containing preheated IPA and a desired amount of $\mathrm{I}_{2}$. The concentration of $\mathrm{I}_{2}$ varied from $0,02 \mathrm{~mol} \mathrm{~L}^{-1}$ to $0,035 \mathrm{~mol} \mathrm{~L}^{-1}$. The reaction was carried out at $95^{\circ} \mathrm{C}$ for different durations up to $10 \mathrm{~h}$. Modified specimens were then soaked in cold acetone to stop the reaction and subsequently extracted with acetone:toluene (1:1) to remove un-reacted reagents and oven dried to determine weight percent gain (WPG). WPG of specimens was calculated using equation;

$$
W P G=\left[\left(W_{m}-W_{o}\right) / W_{o}\right] \times 100
$$

where $W_{o}$ and $\mathrm{W}_{m}$ are oven dried weight of unmodified and chemically modified wood samples, respectively.

The volumetric swelling coefficient (S) and anti-swelling efficiency (ASE) were determined based on the water-soaking method (Rowell and Ellis 1978).

$$
S(\%)=100\left(V_{2}-V_{1}\right) / V_{1}
$$

where $\mathrm{V}_{2}$ is the volume of saturated sample and $\mathrm{V}_{1}$ is volume of oven dried sample.

$$
\operatorname{ASE}(\%)=100\left(S_{u}-S_{m}\right) / S_{u}
$$

where $\mathrm{S}_{\mathrm{u}}$ and $\mathrm{S}_{\mathrm{m}}$ are volumetric swelling coefficients of unmodified and modified samples, respectively.

The ATR-FTIR spectra were measured directly on the wood surfaces (Bruker Germany, Tensor-27 model FTIR Spectrometer; spectral resolution $4 \mathrm{~cm}^{-1} ; 64$ scans). Solid state NMR spectra were obtained by a JEOL ESX $400 \mathrm{MHz}, \mathrm{CP} / \mathrm{MAS}{ }^{13} \mathrm{C}$ NMR spectrometer at the NMR Research Center, Indian Institute of Science, Bengaluru. 


\section{RESULTS AND DISCUSSIONS}

Reaction between IPA and wood in absence of any catalyst (I-0) is insignificant. Figure 2 shows the effect of iodine concentration on weight percent gain (WPG) of modified wood.

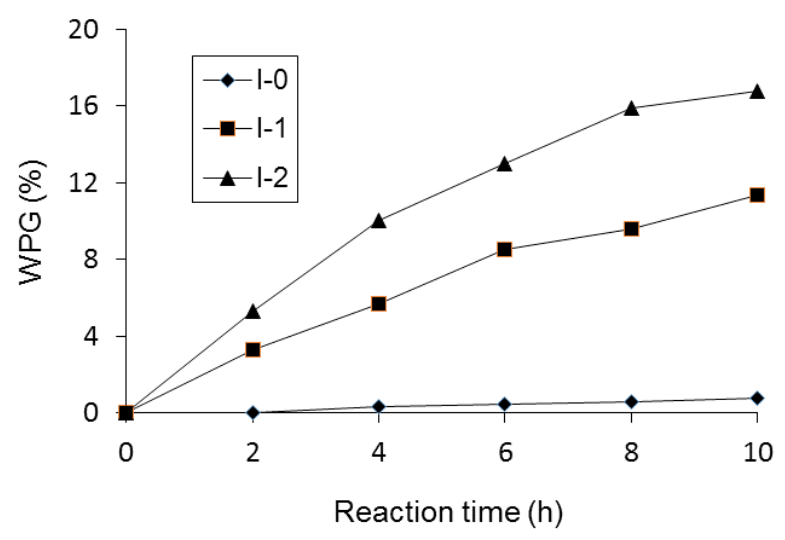

Figure 2. Plot of WPG versus reaction time for IPA modified rubber wood at $95^{\circ} \mathrm{C}$. Catalyst (iodine) concentrations are: $\mathrm{I}-0=0 \mathrm{~mol} \mathrm{~L}^{-1} ; \mathrm{I}-1=0,02 \mathrm{~mol} \mathrm{~L}^{-1}$; and I-2 $=0,035 \mathrm{~mol} \mathrm{~L}^{-1}$.

The average WPG increased with increasing reaction time. Samples up to weight gains of $17 \%$ were obtained using to $0,035 \mathrm{~mol} \mathrm{~L}^{-1}$ (I-2) of iodine. This WPG value compares well with acetylation of wood using acetic anhydride and corresponds to the level of modification necessary for exhibiting good dimensional stability and durability (Rowell 1983, 2006, 2013).

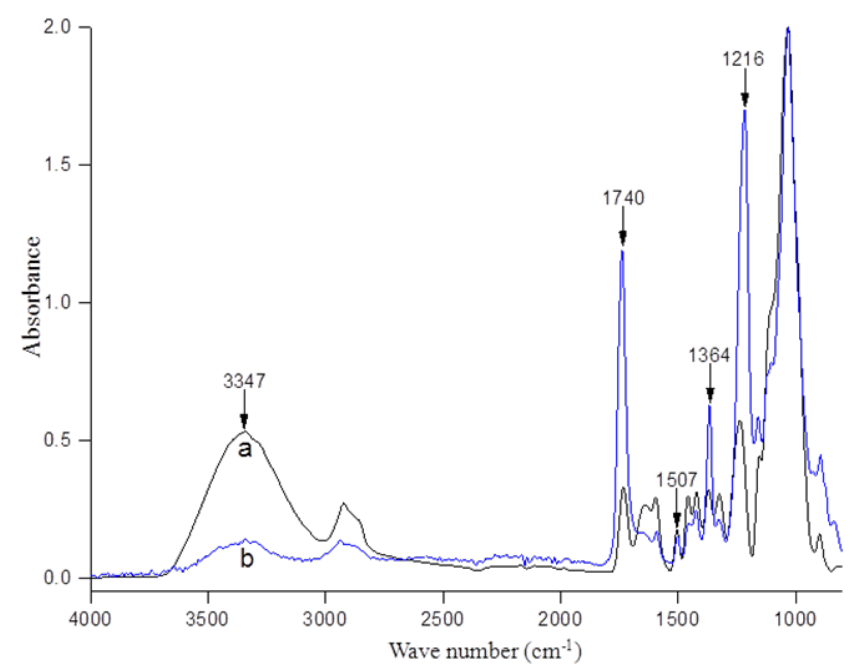

Figure 3. FTIR Spectra of unmodified (a) and modified (b) rubber wood. 
FTIR spectra of unmodified and modified rubberwood are shown in Figure 3. The FTIR spectra of unmodified wood shows strong O-H stretching absorption at $3347 \mathrm{~cm}^{-1}$ and several other well defined peaks due to various functional groups present in cellulose, hemicelluloses and lignin (Harrington et al. 1964, Faix 1992, Pandey 1999). A significant decrease in the O-H stretching band at $3347 \mathrm{~cm}^{-1}$ with a corresponding increase in the $\mathrm{C}=\mathrm{O}$ stretching absorbance at $1740 \mathrm{~cm}^{-1}$ and $\mathrm{C}-\mathrm{O}$ stretching at $1216 \mathrm{~cm}^{-1}$ indicates esterification of wood.

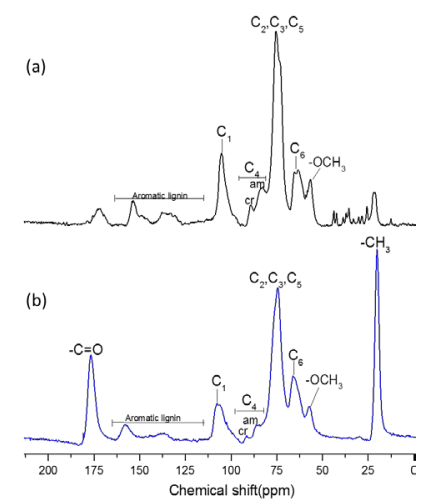

Figure 4. NMR Spectra of unmodified (a) and modified (b) rubber wood.

The modified wood was further characterized by ${ }^{13} \mathrm{C}$ CPMAS NMR (Figure 4). The occurrence of two strong signals at 22,7 and $176,1 \mathrm{ppm}$ in modified wood confirms esterification of wood by IPA. The signal at 22,7 is characteristic of a methyl $\left(-\mathrm{CH}_{3}\right)$ carbon of the acetyl group and a signal at $176,1 \mathrm{ppm}$ arises due to carbonyl $(-\mathrm{C}=\mathrm{O})$ carbon of acetyl group of acetylated wood (Sun et al. 2004).

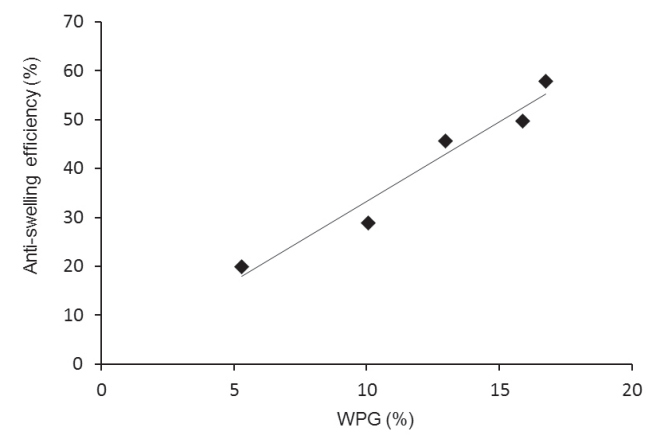

Figure 5. Anti-swelling efficiency (ASE) versus WPG for IPA modified wood using iodine catalyst.

The dimensional stability of modified wood was determined by estimating the volumetric swelling coefficient (S) and anti-shrink/anti-swell efficiency (ASE), using the repeated water-soaking method (Rowell and Ellis 1978). After modification, the volumetric swelling coefficient of modified wood was reduced significantly. The values of ASE after first water soaking cycle against weight gain are plotted in Figure 5. Modified wood exhibited a high ASE value which increases with increase in WPG values. Anti-Swelling Efficiency up to $\sim 60 \%$ was obtained corresponding to WPG values of $\sim 17 \%$. This indicates high dimensional stability of IPA modified wood. 
Above results indicate that iodine is a good catalyst for chemical modification of wood using IPA. The modified wood has high dimensional stability. Modification with IPA may have advantages since there is no acid byproduct.

\section{CONCLUSIONS}

A process of acetylation of solid wood with IPA in presence of iodine has been reported. A high level of modification ( $\sim 17 \%$ WPG) was achieved. The average WPG increased with increasing reaction time and catalyst concentration. Modified wood exhibited high dimensional stability.

\section{ACKNOWLEDGEMENT}

This research was supported by CSIR New Delhi (Grant No. 38(1357)/13/EMR (II)).

\section{REFERENCES}

Can, A.; Sivrikaya, H. 2016. Dimensional stabilization of wood treated with Tall oil dissolved in different solvents. Maderas. Ciencia y Tecnología 18(2):317-324.

Faix, O. 1992. Fourier transform infrared spectroscopy. In: Methods in Lignin Chemistry. Eds. Lin, S.Y., Dence, C.W. Springer-Verlag, New York. pp. 83-109.

Giridhar, B.N.; Pandey, K.K. 2016. UV resistance and dimensional stability of wood modified with isopropenyl acetate. J Photochem Photobiol B: Biology 155:20-27.

Harrington, K.J.; Higgins, H.G.; Michell, A.J. 1964. Infrared spectra of Eucalypus regnans F. Muell. and Pinus radiata D. Don. Holzforschung 18:108-113.

Hill, CAS. 2006. Wood Modification: Chemical, Thermal and Other Processes. John Wiley and Sons, Ltd., Chichester.

Jebrane, M.; Sèbe, G.; Cullis, I.; Evans, P. D. 2009. Photostabilization of wood using aromatic vinyl esters. Polym Degrad Stabil 94:151-157.

Lopes, D.B.; Mai, C.; Militz, H. 2014. Marine borers resistance of chemically modified Portuguese wood. Maderas. Ciencia y Tecnología 16(1):109-124.

Lopes, D.B.; Mai, C.; Militz, H. 2015. Mechanical properties of chemically modified Portuguese pinewood. Maderas. Ciencia y Tecnología 17(1):179-194.

Matsuda, H. 1996. Chemical modification of solid wood. In: Chemical Modification of Lignocellulosic Materials. Ed. Hon, D.N.S. Marcel Dekker, New York. pp. 159-183.

Pandey, K.K. 1999. A study of chemical structure of softwood and hardwood and wood polymers by FTIR spectroscopy. J Appl Polym Sci 71:1969-1975. 
Rowell, R.M. 1983. Chemical modification of wood. Forest Products Abstracts 6:363-382.

Rowell, R.M. 2006. Chemical modification of wood: A short review. Wood Mat Sci Eng 1:29-33.

Rowell, R.M. 2013. Chemical modification of wood. In: Handbook of Wood Chemistry and Wood Composites. Ed. Rowell, RM. Taylor and Francis, CRC press, Florida. pp. 537-598.

Rowell, R.M.; Ellis, W.D. 1978. Determination of dimensional stabilization of wood using the water-soaked method. Wood Fiber Sci 10:104-111.

Sun, X.F.; Sun, R.C.; Sun, J.X. 2004. Acetylation of sugarcane bagasse using NBS as a catalyst under mild reaction conditions for the production of oil sorption-active materials. Biores Techn 95:343350. 